\title{
NBSIR 73-264
}

\section{Examination of Failed One Inch \\ Black Iron Pipe Natural Gas \\ Service Line, lowa Public Service Company, Eagle Grove, lowa}

\section{T. Robert Shives}

Mechanical Properties Section

Metallurgy Division

Institute for Materials Research

National Bureau of Standards

Washington, D. C. 20234

August 30,1973

Failure Analysis Report

Prepared for

Office of Pipeline Safety

Department of Transportation

Washi :gton, D. C. 20590 

NBSIR 73-264

\section{EXAMINATION OF FAILED ONE INCH \\ BLACK IRON PIPE NATURAL GAS \\ SERVICE LINE, IOWA PUBLIC SERVICE \\ COMPANY, EAGLE GROVE, IOWA}

\section{T. Robert Shives}

Mechanical Properties Section

Metallurgy Division

Institute for Materials Research

National Bureau of Standards

Washington, D. C. 20234

August 30,1973

Failure Analysis Report

"This document has been prepared for the use of the Office of Pipeline Safety, Department of Transportation, Washington, D.C. Responsibility for its further use rests with that agency. NBS requests that if release to the general public is contemplated, such action be taken only after consultation with the Office of Public Affairs at the National Bureau of Standards."

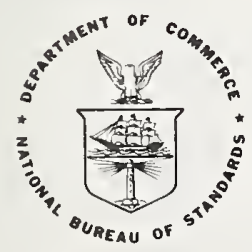

U. S. DEPARTMENT OF COMMERCE, Frederick B. Dent, Secretary 

1. INTRODUCTION $\ldots \ldots \ldots \ldots \ldots \ldots \ldots \ldots \ldots \ldots \ldots \ldots \ldots \ldots$

1.1 Reference $\ldots \ldots \ldots \ldots \ldots \ldots \ldots \ldots \ldots \ldots \ldots \ldots \ldots$

1.2 Background Information ................ I

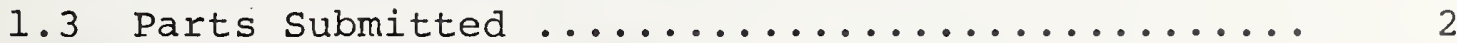

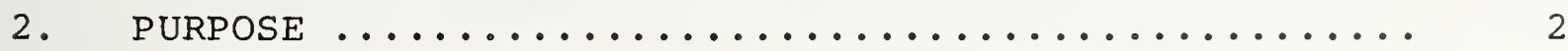

3. EXAMINATIONS, TESTS, AND MEASUREMENTS PERFORMED ..... 2

4. RESULTS OF EXAMINATIONS, TESTS AND MEASUREMENTS .... 3

4.1 Visual and Macroscopic Examination .......... 3

4.1 .1 Submitted fracture $\ldots \ldots \ldots \ldots \ldots \ldots \ldots \ldots$

4.1 .2 NBS produced fractures ............. 3

4.2 Scanning Electron Microscope Examination ...... 4

4.3 Metallographic Examination ............... 4

4.4 Hardness Measurements.................... 5

5. DISCUSSION OF RESULTS ........................... 5

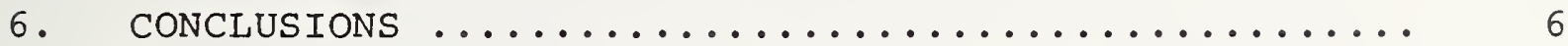

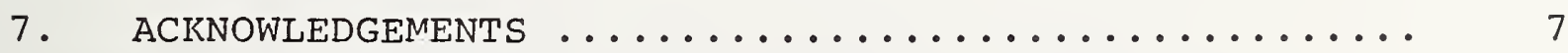

REFERENCES $\ldots \ldots \ldots \ldots \ldots \ldots \ldots \ldots \ldots \ldots \ldots \ldots \ldots \ldots \ldots \ldots \ldots$

FIGURES

1. Submitted failed natural gas service line pipe parts

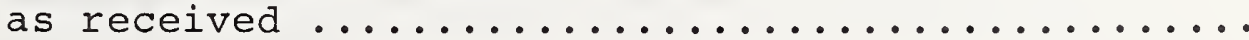

2. Setup for bend test of pipe length ............ 9

3. Setup for uniaxial tensile test of pipe length ..... 10 

FIGURES (Continued)

4. Fracture surfaces of the submitted failure as

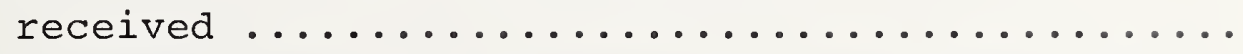

5. SEM of the fracture surface of the submitted failure in the area of densest rust ...........

6. SEM of the fracture surface of the submitted failure in the area of densest rust ...........

7. SEM of the fracture surface of the submitted failure in area $\mathrm{B} \ldots \ldots \ldots \ldots \ldots \ldots \ldots \ldots \ldots$

8. SEM of the fracture surface of the submitted failure in an area away from that containing

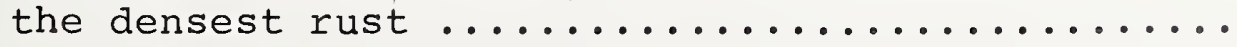

9. SEM of the fracture surface of the submitted failure in an area away from that containing

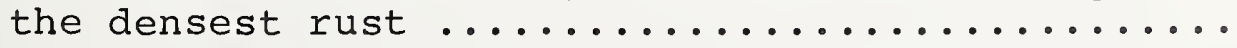

10. SEM of the fracture surface of the NBS

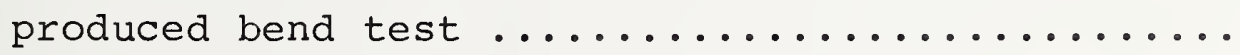

11. SEM of the fracture of the NBS produced uniaxial tensile test of material from the

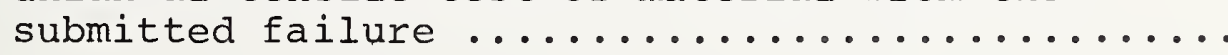

12. Unetched longitudinal cross section through

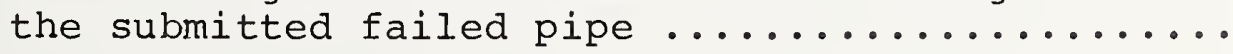

13. Etched longitudinal cross sections showing

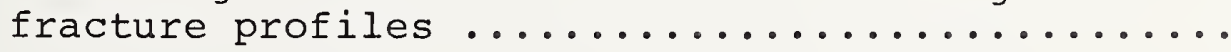

14. Etched longitudinal cross sectior through submitted fractured pipe showing deformation at and near the root of the thread one thread

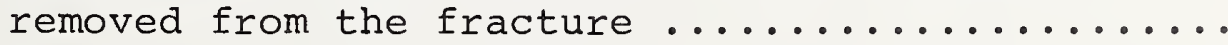

15. Etched longitudinal cross section through submitted failed pipe showing representative

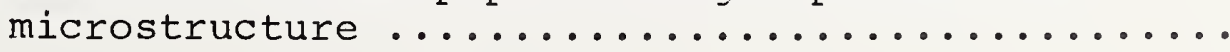

16. Etched representative longitudinal cross section through stock standard weight black iron pipe... 


\section{.}


A fractured one inch black iron pipe natural gas service line which connected to a building involved in an explosion and fire in Eagle Grove, Iowa on February 2, 1973 was examined in order to determine the mode of fracture and whether there was a pre-existing crack.

The fracture was ductile in nature and appeared to have occurred due to bending stresses caused by loading from an external source. There was no evidence found to indicate the presence of a pre-existing crack.

The material in the submitted pipe was clean with few inclusions. The microstructure appeared normal for a very low carbon steel in the normalized heat treatment condition.

The pipe appeared to satisfy currently applicable ASTM standards for ultimate tensile strength (determined indirectly from hardness measurements) for grade A electric resistance welded steel pipe, and carbon content (by visual comparison of microstructures) for both grades $A$ and $B$ electric resistance welded steel pipe. 
Examination of Failed one Inch Black Iron Pipe Natural Gas Service Line, Iowa Public Service Company, Eagle Grove, Iowa

\section{INTRODUCTION}

\subsection{Reference}

office of Pipeline Safety, Department of Transportation, Washington, D. C. This investigation was conducted at the request of $\mathrm{Mr}$. Lance $\mathrm{F}$. Heverly of OPS under order number DOT-AS-10041. The request was made on February 28, 1973.

\subsection{Background Information}

The information in this section was furnished by Mr. Lance F. Heverly of the Office of Pipeline Safety.

At 6:18 P.M. on February 2, 1973, there was an explosion followed by a fire that destroyed two buildings and severely damaged another at 218-222 West Broadway Street, Eagle Grove, Iowa. An accumulation of natural gas apparently provided an atmosphere conducive to explosion and fire. At the time of the incident, the ground was frozen. Pressure in the Eagle Grove gas distribution system in that area was seven psig.

Two days after the incident, the service line to one of the destroyed buildings was pressure tested for gas leaks. At the time of the explosion, the building wall had fallen on the service line above ground outside the building, and a bulldozer had apparently hit the service line inside the basement before the leak test was performed. Two leaks were found. One of these was in the threaded portion of a horizontal pipe at the downstream edge of a buried $90^{\circ}$ elbow located just outside the basement wall of the building. The riser pipe and the elbow were broken off by fracturing the horizontal pipe at the edge of the elbow. At the point of fracture, the pipe was about two feet deep in the ground. The horizontal piece was removed with a mass of concrete attached to it. The concrete had apparently been used to fill a void in the stone wall around the service line. The void was evidently produced when the line was installed.

Examination of the fracture surfaces of the one inch pipe service line by an ops representative in the field indicated a superficial coating of rust on both surfaces, except for one mating area on each surface where the rust appeared to be denser. The region of densest rust (corrosion product) was between the $6 \mathrm{O}^{\prime} \mathrm{clock}$ and $90^{\prime} \mathrm{clock}$ positions when looking into the downstream end of the $90^{\circ}$ elbow with the pipe positioned as it had been in service. 

Two items were submitted for examination: 1) the length of one inch black iron riser pipe connected to the $90^{\circ}$ elbow which in turn was connected to one end of the fractured horizontal one inch black iron pipe, and 2) the remainder of the fractured horizontal pipe to which the mass of concrete was attached. These parts are shown as received at NBS in figure 1. The material was delivered to the NBS Mechanical Properties Section by Mr. Heverly on February 28, 1973.

\section{PURPOSE}

The Office of Pipeline Safety, DOT, requested that the Mechanical Properties Section, NBS, determine the nature of the fracture, whether there had been a pre-existing crack, and the probable cause of failure.

\section{EXAMINATIONS, TESTS, AND MEASUREMENTS PERFORMED}

Several tests were performed in order to produce fracture surfaces for comparison with the submitted fracture surfaces. These tests, all conducted at about $70^{\circ} \mathrm{F}$, were as follows:

A) A ten inch length of stock, standard weight, one inch diameter black iron pipe threaded at one end tested to fracture in bending as shown in figure 2 .

B) A ten inch length taken from the submitted horizontal fractured pipe threaded at one end tested to fracture in bending in the same manner as in " $A$ " above.

C) An eleven inch length of stock, standard weight, one inch diameter black iron pipe threaded at both ends and pulled to fracture in uniaxial tension as shown in figure 3 .

D) An eight inch length taken from the undamaged remainder of the bend test specimen threaded at both ends and pulled to fracture in uniaxial tension as in "C" above.

The fracture surfaces of the submitted failure and the failures produced in " $A$ " through " $D$ " above were examined visually and macroscopically. Selected areas of the fracture surfaces of the submitted failure and of test pieces from "B" and "D" were examined with the scanning electron microscope (SEM). In addition, cross sections, some of which intersected the fracture surfaces of the submitted fracture and the NBS produced fractures "A", "B", and "D", were examined metallographically. Hardness measurements were made on transverse cross sections through the submitted failure and the stock black iron pipe. 

Specimens for SEM examinations, for tests "B" and "D", and the cross sections for hardness measurements and metallographic examinations from the submitted failed pipe were all taken from the long portion of the horizontal pipe piece to which the concrete had been attached. The small threaded portion of the horizontal pipe that remained in the elbow was examined visually and macroscopically, but was otherwise undisturbed.

\section{RESULTS OF EXAMINATIONS, TESTS AND MEASUREMENTS}

\subsection{Visual and Macroscopic Examination}

\subsubsection{Submitted fracture}

The two opposing fracture surfaces of the submitted failure are shown as received in figure 4. The pipe had fractured in the threaded end at the root of a thread at the end of a $90^{\circ}$ elbow as can be seen in figure $4 \mathrm{a}$. The short part of the fractured piece remained in the elbow.

The concrete was removed from the horizontal pipe piece in order to examine the entire submitted length. The horizontal piece, the riser, and the elbow were all covered with what appeared to be a mixture of fiberglass and coal tar. The pipe appears to have been fabricated by an electric resistance welding process.

Both of the fracture surfaces were covered with corrosion product (rust) which for the most part appeared to be superficial except for the region discussed in Section 1.2 where the rust appeared to be denser. This region was between the $6 \mathrm{o}^{\prime} \mathrm{clock}$ and $9 \mathrm{O}^{\prime} \mathrm{clock}$ positions when looking into the downstream end of the $90^{\circ}$ elbow with the pipe positioned as it had been in service. The heaviest concentration was at about the 7-7:30 o'clock position (arrow A, figure 4a). The dense rust appeared on the mating position of the opposing fracture surface (arrow A, figure 4b). There were mating areas on both fracture surfaces adjacent to the region of densest rust which appeared to have suffered mechanical damage (arrows B, figure 4). The apparent last part to fail is indicated by arrows C, figure 4 .

\subsubsection{NBS produced fractures}

Each of the four pipe specimens tested at NBS ("A" through "D", Section 3) failed at the root of a thread adjacent to the outside of the threaded fixture to which it was attached. for testing. A considerable amount of ductility was exhibited in each case. 

After the submitted fracture surface was cleaned, the appearance of it and the appearance of the NBS produced fracture surfaces were very similar. The tearing and deformation at the apparent last part to fail in the submitted fracture (ärrow $C$, figure 4a) more closely approximated that of the NBS bend test fractures than those produced by uniaxial tensile testing. Since the rust was easily removed from the submitted fracture by ultrasonic cleaning with water and detergent, the rust over the entire fracture surface was apparently superficial.

\subsection{Scanning Electron Microscope Examination}

The submitted failure and the NBS produced failures "B" and "D" all exhibited dimpled rupture over essentially their entire fracture. surfaces indicating that all the fractures were ductile in nature. Scanning electron photomicrographs (SEM's), showing features representative of the submitted fracture, are shown in figures 5 through 9 . Figures 5 and 6 were taken in an area which appeared to exhibit the densest rust (area $A$, figure $4 \mathrm{~b}$ ). They show dimpled rupture. Figure 7 (area B, Figure 4b) shows dimpled rupture with considerable mechanical damage. The edge of the thread root can be seen near the bottom of the figure. Figures 8 and 9 were taken in two different areas away from that exhibiting the dense rust. Dimpled rupture again is essentially the only fracture feature exhibited. No evidence was found to indicate the presence of a pre-existing crack.

SEM photomicrographs representative of the fracture features of specimens from " $B$ " and " $D$ " are shown in figures 10 and 11 , respectively. Both fracture surfaces exhibited essentially all dimpled rupture.

4.3 Metallographic Examination

Figure 12 shows a representative unetched field from a longitudinal cross section through the submitted failed pipe. The concentration and size of the inclusions are small and are not considered excessive for this material.

Low magnification photomicrographs of etched, longitudinal sections showing fracture profiles of the submitted failure and NBS produced failures "B" and "D" are shown in figures 13a, $b$, and $c$, respectively. The fracture profile in each case is shown vertically at the right of the figure. A considerable amount of deformation and necking can be seen in all three specimens, indicating ductility in the material. Some 

deformation was exhibited in the interior of the cross section adjacent to the root of the first thread beyond the fracture of the submitted failure (figure 14). Some of the deformation near the surface at the thread root appears to have been induced into the material by the threading operation. There are a few large stringers (inclusions) in this field which is not typical of the material in the submitted pipe.

An etched microstructure representative of the material away from the deformed regions is shown in figure 15. The microstructure consists of ferrite (white) and a small amount of pearlite (dark patches). This is the microstructure of a normalized very low carbon steel.

Metallographic examination of the stock black iron pipe material revealed a considerably higher inclusion content than found in the submitted material. An etched microstructure from a longitudinal cross section through the stock pipe is shown in figure 16. The microstructure consists of ferrite (white) and pearlite (dark patches). There is some evidence of a Widmanstätten structure. Comparison of microstructures indicates that the material from the stock pipe has a significantly greater amount of pearlite, and consequently, a significantly higher carbon content than that of the submitted pipe.

\subsection{Hardness Measurements}

The Rockwell hardness of the submitted pipe ranged from $R_{45} \mathrm{~T}$ 23 to 30.5 (based on 18 measurements) while that of the stock pipe ranged from $R_{45} \mathrm{~T} 32$ to 38 (based on eight measurements).

\section{DISCUSSION OF RESULTS}

Even though there were relatively small areas of fairly dense rust on the opposing fracture surfaces of the submitted failure, the rust was easily removed when the fracture was cleaned with detergent and water in an ultrasonic cleaner. A fractographic examination revealed no evidence to indicate the presence of a pre-existing crack in the pipe. The fracture was quite ductile, with dimpled rupture being essentially the only fracture feature exhibited (except for some mechanical damage). 

When tested to failure both in bending and in tension, samples of the stock black iron pipe and samples from the submitted failed pipe produced fractures which exhibited dimpled rupture as essentially the only fracture feature present. This indicates that all the fractures were ductile. The bend specimens had more of a tear lip than did the tensile specimens. Comparison of the submitted fracture to the NBS produced fractures indicated that the failure in the submitted pipe was probably due to bending stresses caused by loading from an external source.

The microstructure of the submitted pipe material, consisting of ferrite and pearlite, appears to be normal for a normalized very low carbon steel. An ASTM specification giving heat treatment requirements for black iron pipe could not be found.

One of the ASTM Standards ${ }^{1}$ which currently applies to pipe of the type used in applications such as that of the submitted pipe specifies a maximum carbon content of $0.25 \%$ for grade $A$ and $0.30 \%$ for grade B. There is no minimum carbon requirement. The microstructure of the submitted pipe indicates that the carbon content is well below the maximum allowed.

The greater hardness of the stock pipe compared to the submitted pipe is probably due to the higher carbon content of the stock pipe. There appear to be no hardness requirements in the ASTM standards.

The current strength requirements ${ }^{1}, 2,3$ for electric resistance welded steel pipe specify a minimum ultimate tensile strength of $48 \mathrm{ksi}$ for grade $\mathrm{A}$ pipe and $60 \mathrm{ksi}$ for grade $B$ pipe. The approximate ultimate tensile strength equivalent to an average Rockwell 45T hardness of 26.7 (as determined for the submitted pipe) is about 49 to $50 \mathrm{ksi}^{4}$ when compared to data for an AISI 1008 steel. The pipe material thus appears to satisfy current ultimate tensile strength requirements for grade A electric resistance welded steel pipe.

\section{CONCLUSIONS}

1. The fracture of the submitted pipe was essentially completely ductile, dimpled rupture being the only fracture feature exhibited (except for some mechanical damage). 

2. Since the rust was easily removed in an ultrasonic bath with water and detergent, it was essentially all of a superficial nature.

3. There was no evidence to indicate the presence of a preexisting crack.

4. Comparison of the submitted fracture with laboratory produced fractures indicates that the submitted failure was probably due to bending caused by loading from an external source.

5. The carbon content and ultimate tensile strength of the material from the submitted pipe appear to satisfy current ASTM requirements for grade A electric resistance welded steel.

6. The microstructure appears normal for a normalized very low carbon steel.

\section{ACKNOWLEDGEMENT}

Dr. M. L. Picklesimer, Chief of the NBS Mechanical Properties Section, provided a number of suggestions for the conduct of this investigation. Mr. L. C. Smith, also of the NBS Mechanical Properties Section, prepared the specimens for the mechanical tests and for the metallographic and SEM examinations.

\section{REFERENCES}

1 ASTM Standard A53-71, American Society for Testing and Materials, Book 1, 1972.

2 ASTM Standard A120-71, American Society for Testing and Materials, Book 1, 1972.

3 ASTM Standard Al35-69, American Society for Testing and Materials, Book 1, 1972.

4 Metals Handbook, 8th Edition, Volume 1, American Society for Metals, 1961. 



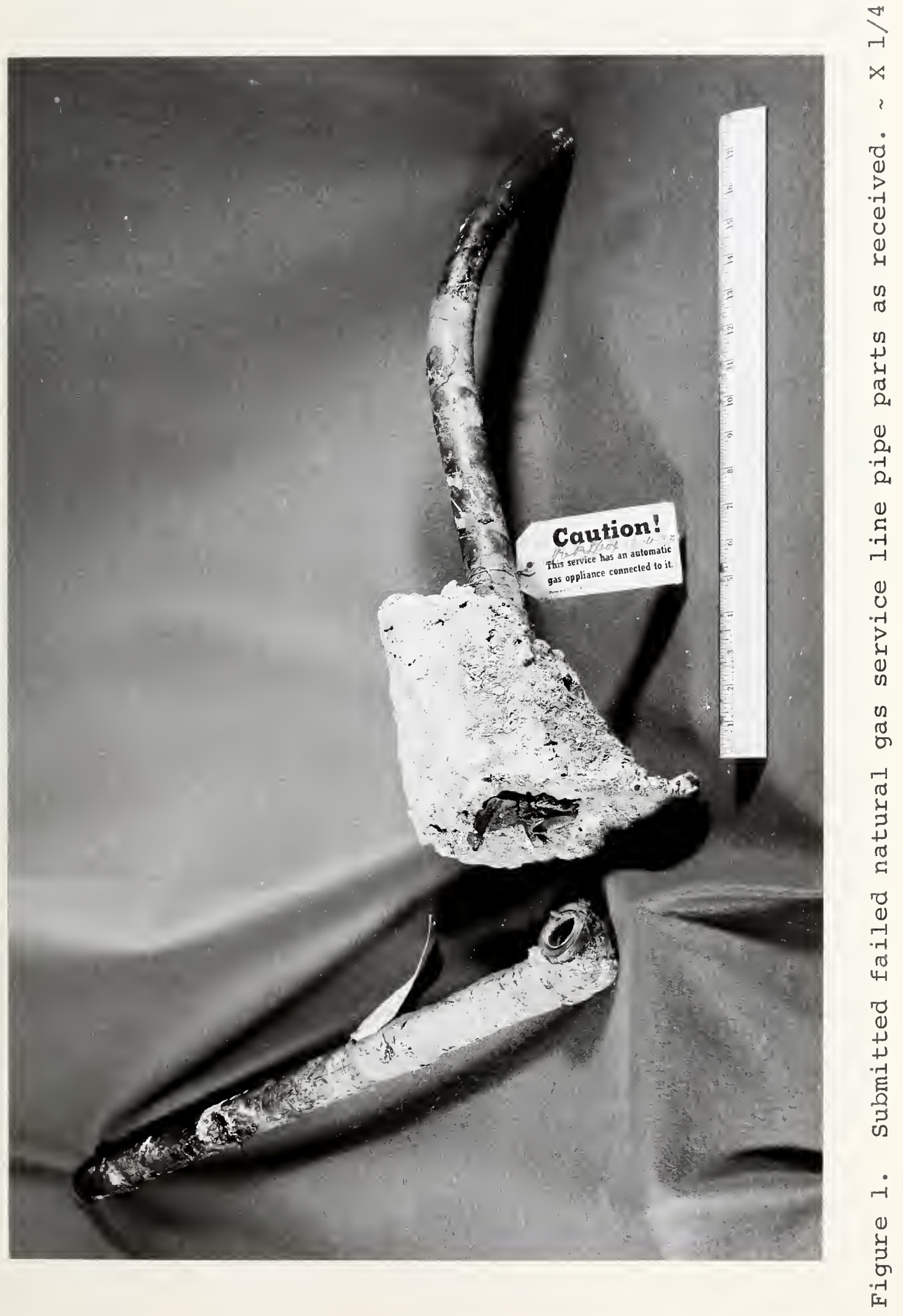





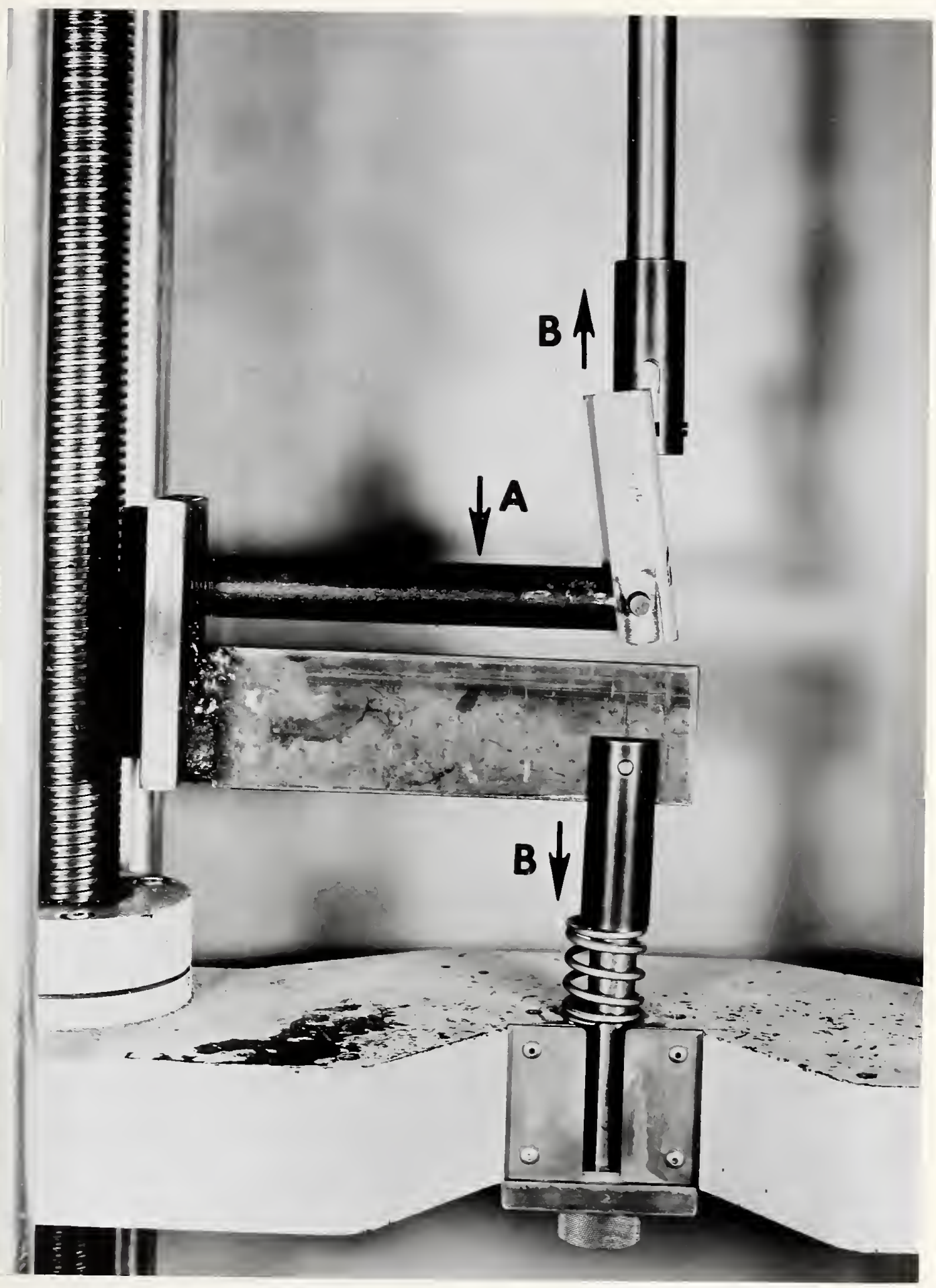

Figure 2. Setup for bend test of pipe length. Pipe specimen is indicated by arrow A. Arrows B indicate the direction of load application. The specimen is threaded on the left end. 



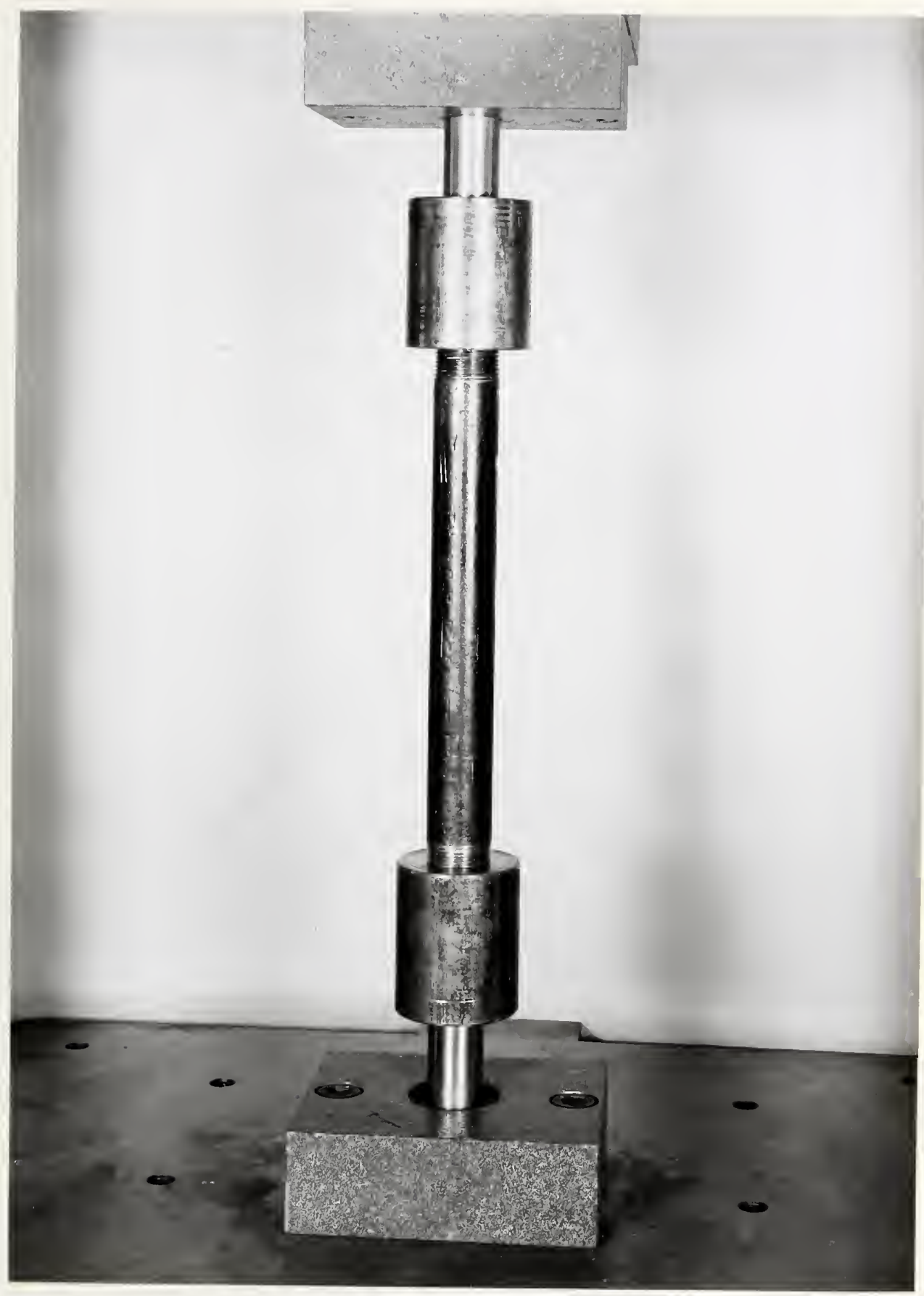

Figure 3. Setup for uniaxial tensile test of pipe length. Pipe is threaded on both ends. 



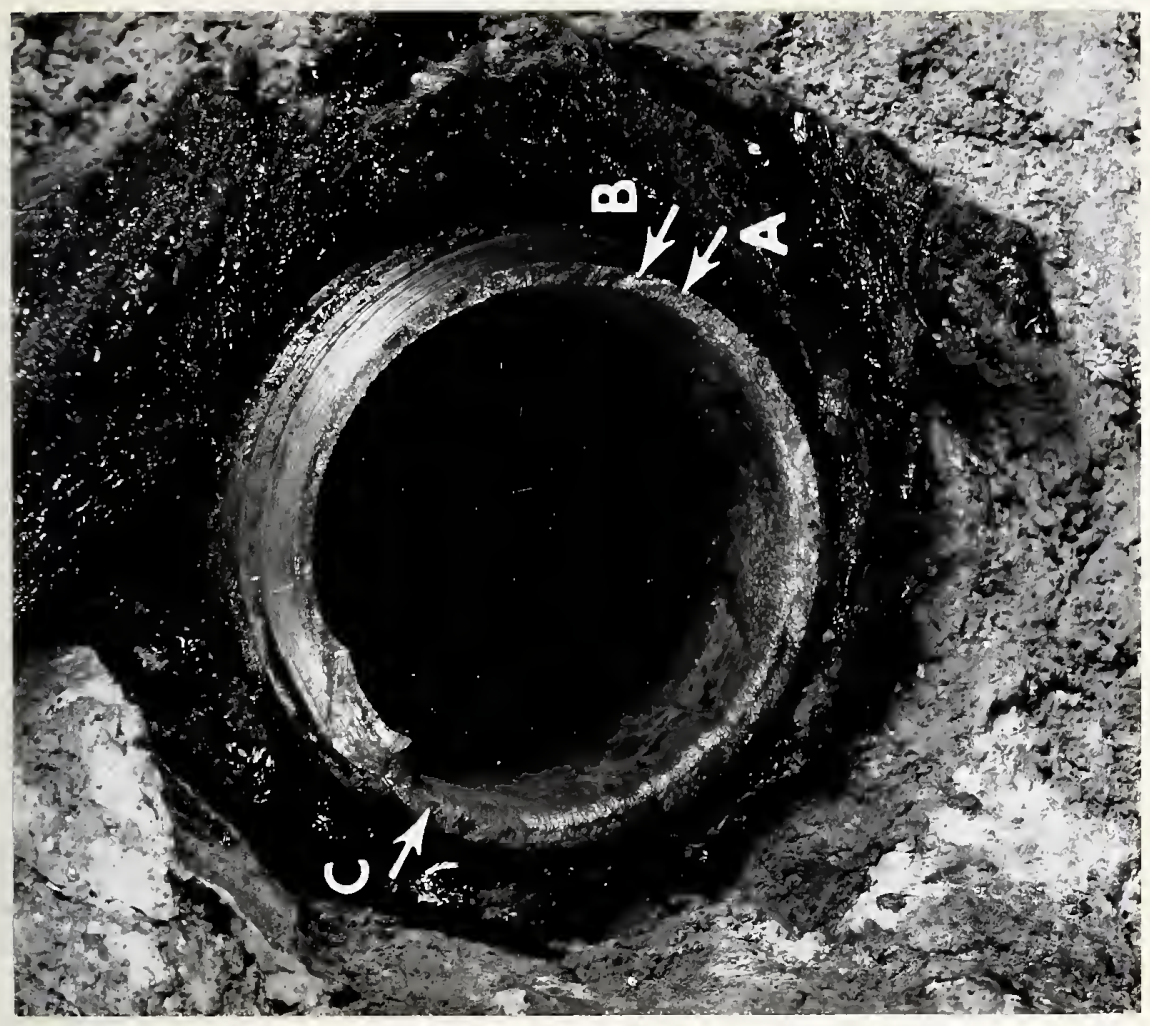

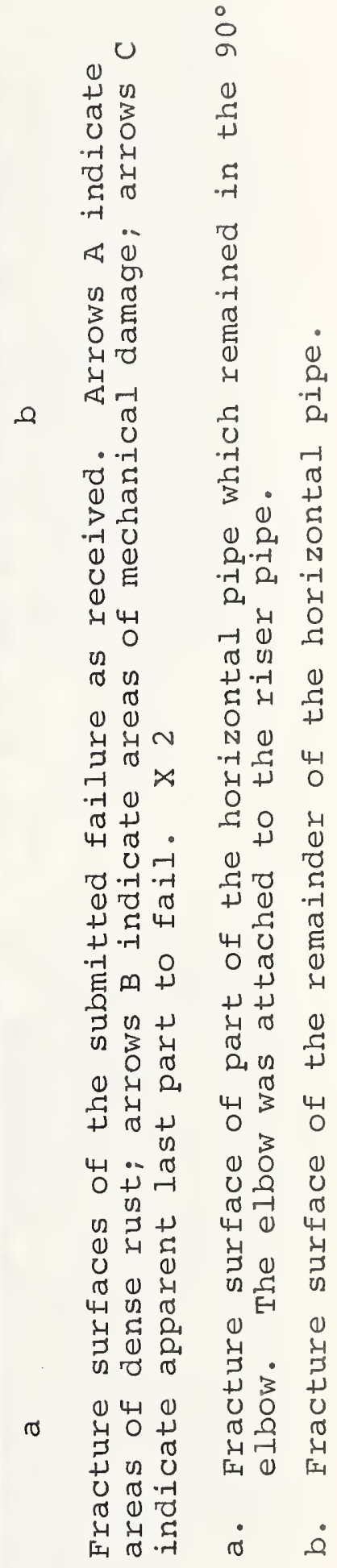

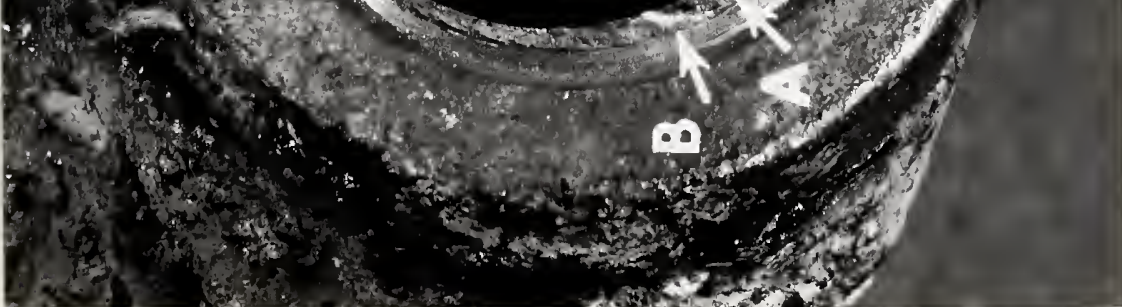





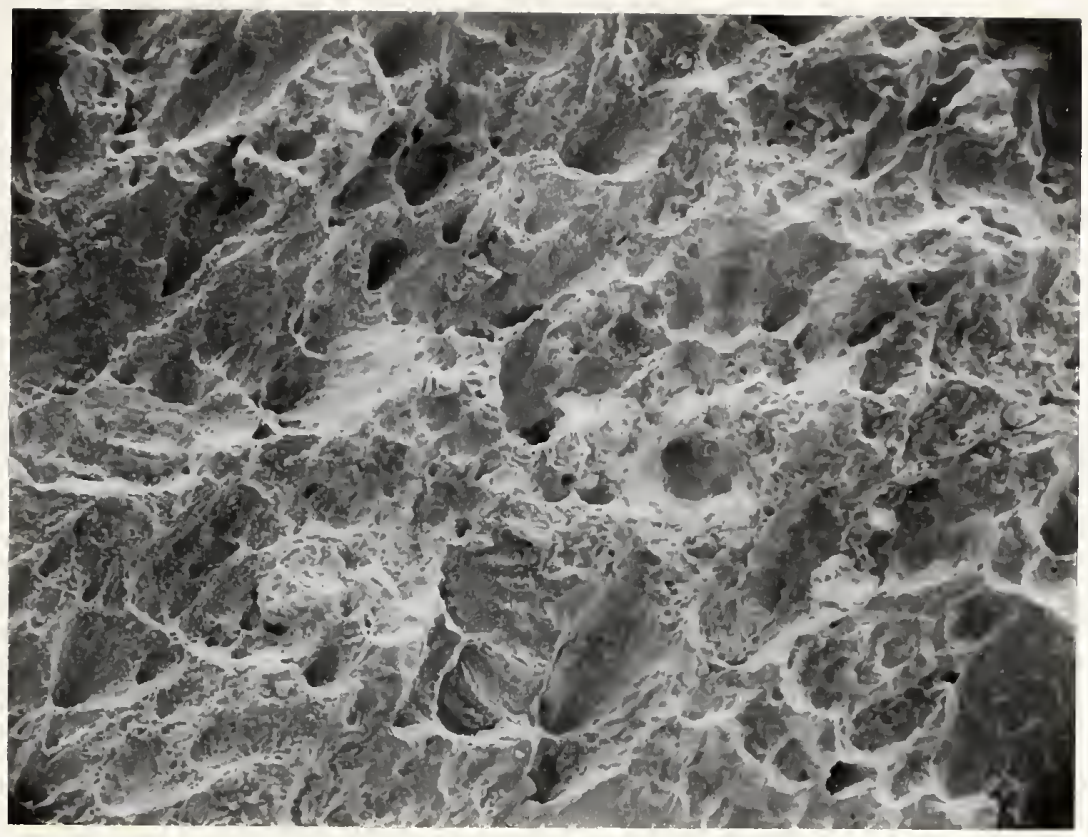

Figure 5. SEM of the fracture surface of the submitted failure in the area of densest rust (area $A$, figure $4 \mathrm{~b}$ ) showing dimpled rupture. X 650

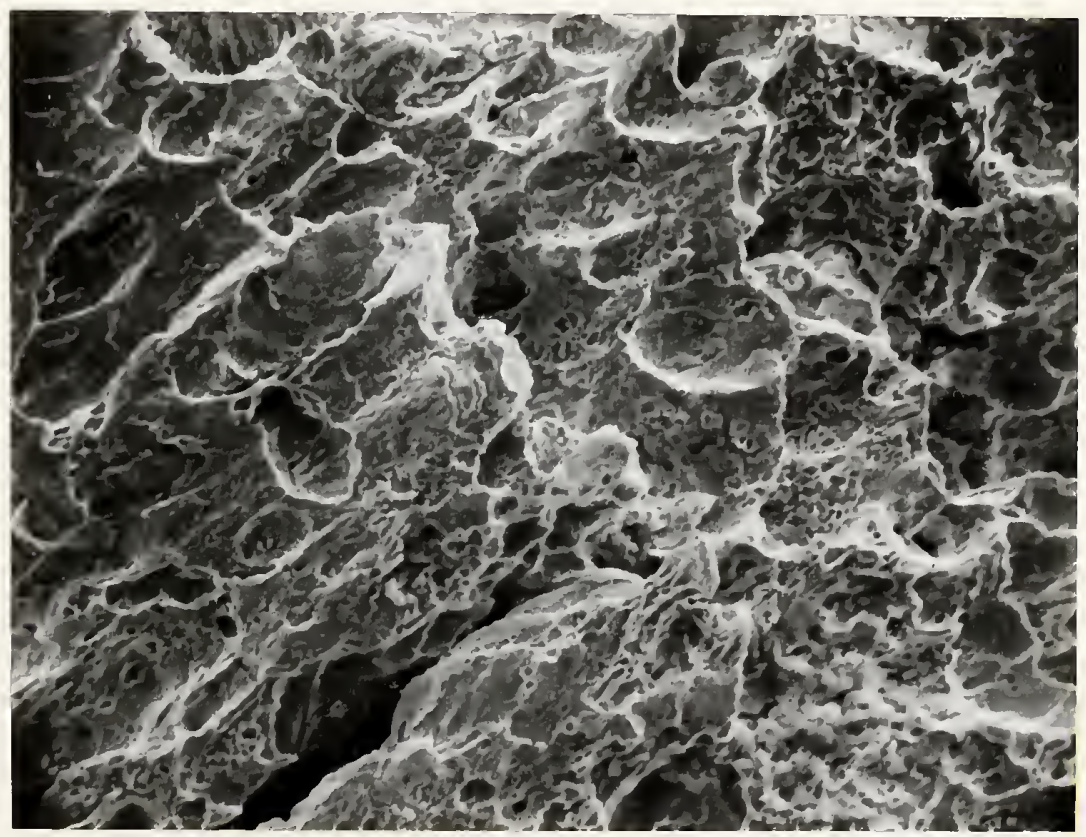

Figure 6. SEM of the fracture surface of the submitted failure in the area of densest rust (area $A$, figure 4b) showing dimpled rupture. A secondary crack can be seen in the lower left portion of the figure. X 1300 



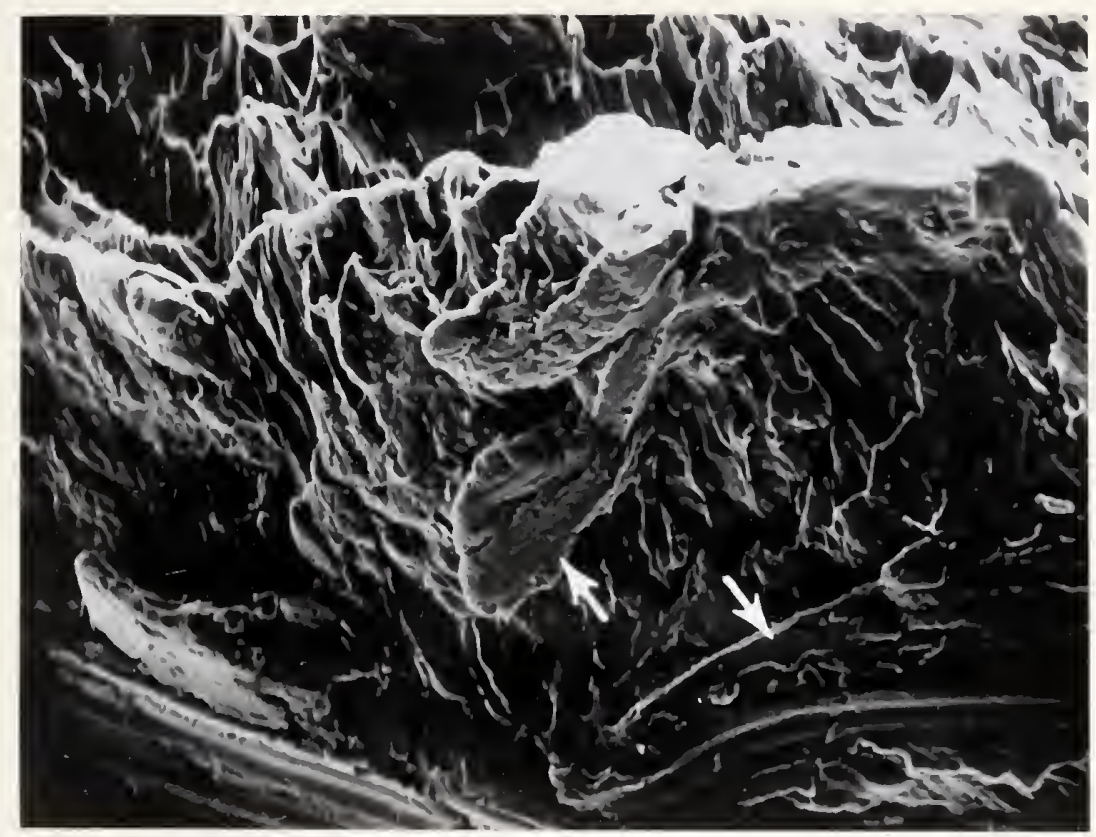

Figure 7. SEM of the fracture surface of the submitted failure in area B, figure $4 \mathrm{~b}$, showing mechanical damage (arrows) and dimpled rupture. Edge of thread root can be seen at lower left. X 550

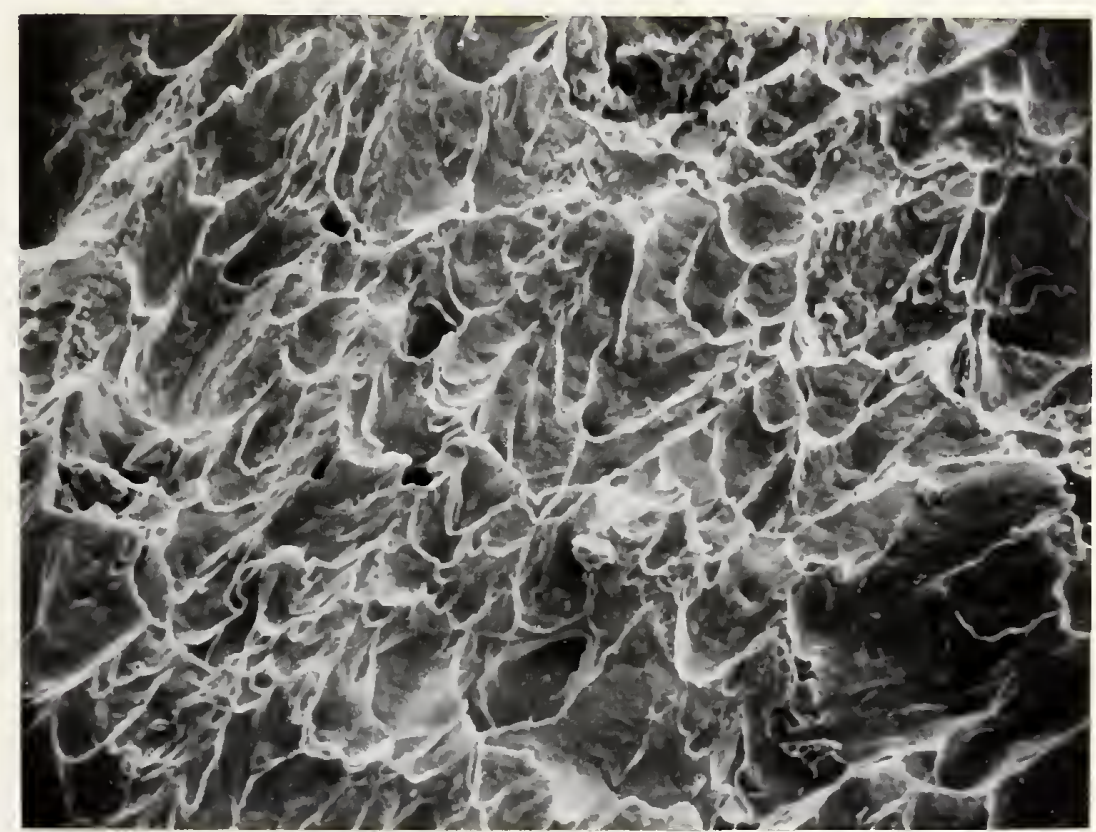

Figure 8. SEM of the fracture surface of the submitted failure in an area away from that containing the densest rust showing dimpled rupture. X 1100 



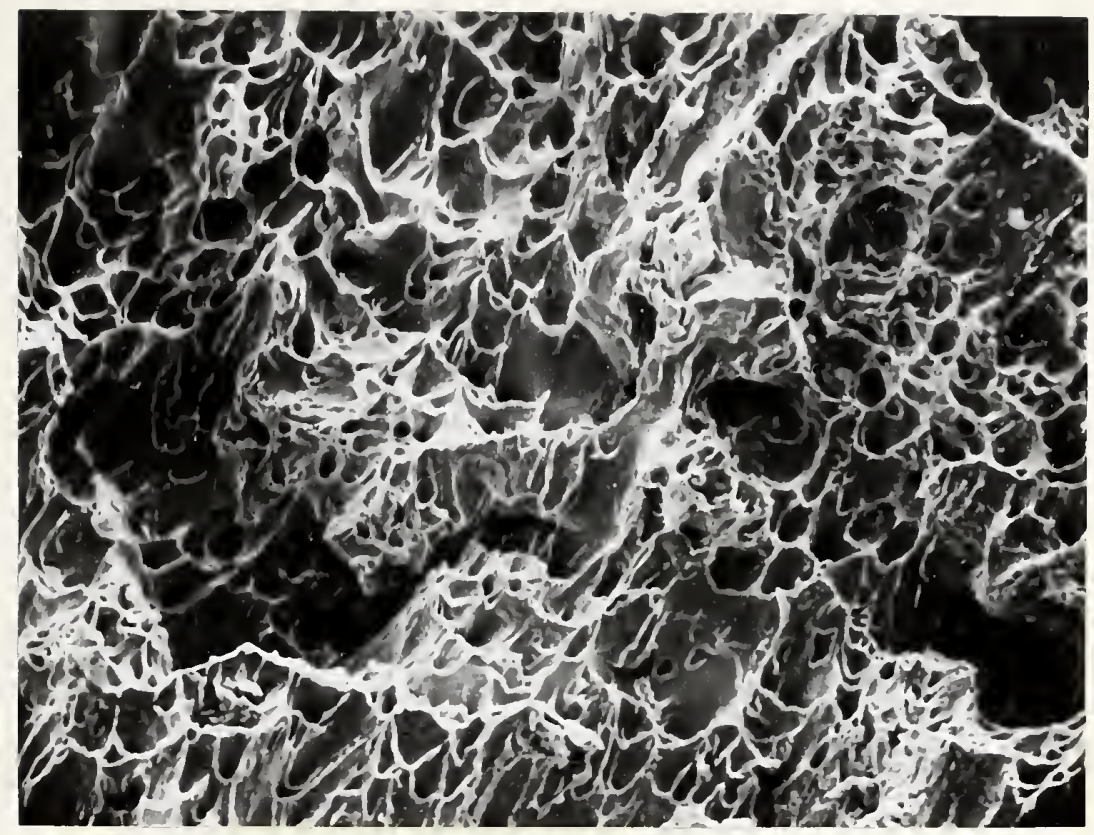

Figure 9. SEM of the fracture surface of the submitted failure in an area away from that containing the densest rust showing dimpled rupture. X 600

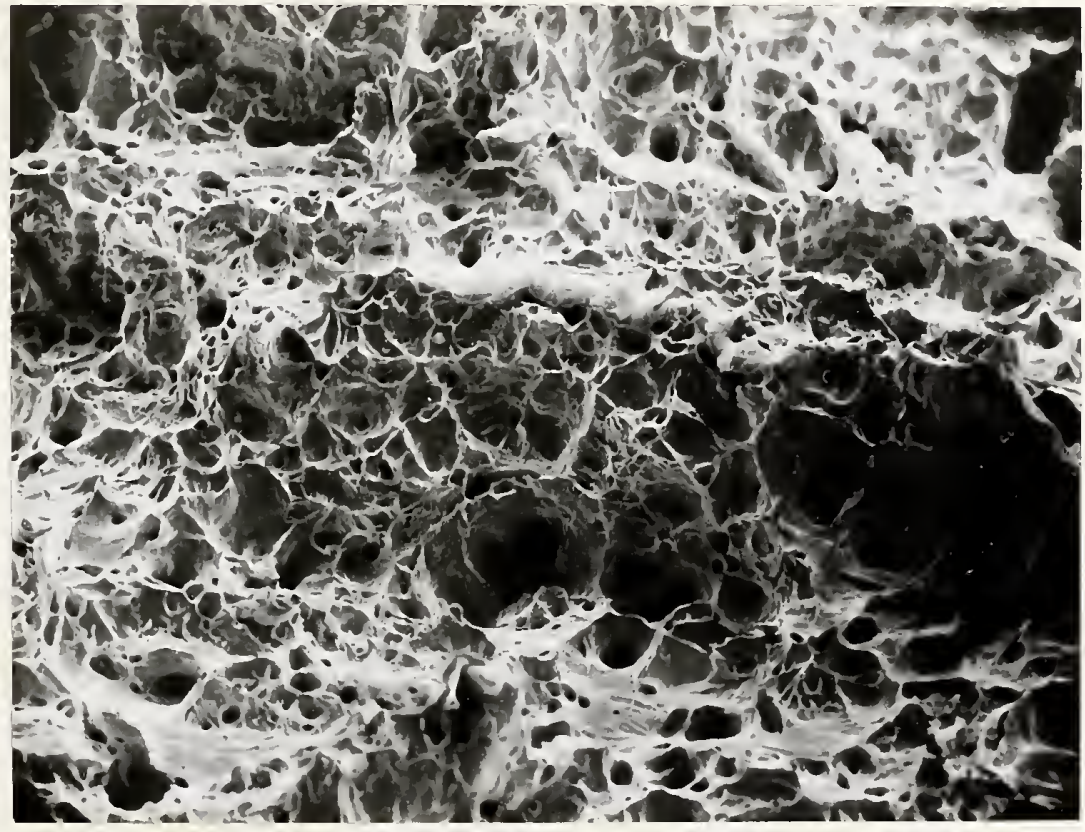

Figure 10. SEM of the fracture surface of the NBS produced bend test (test $B$ ) showing dimpled rupture. X 550 



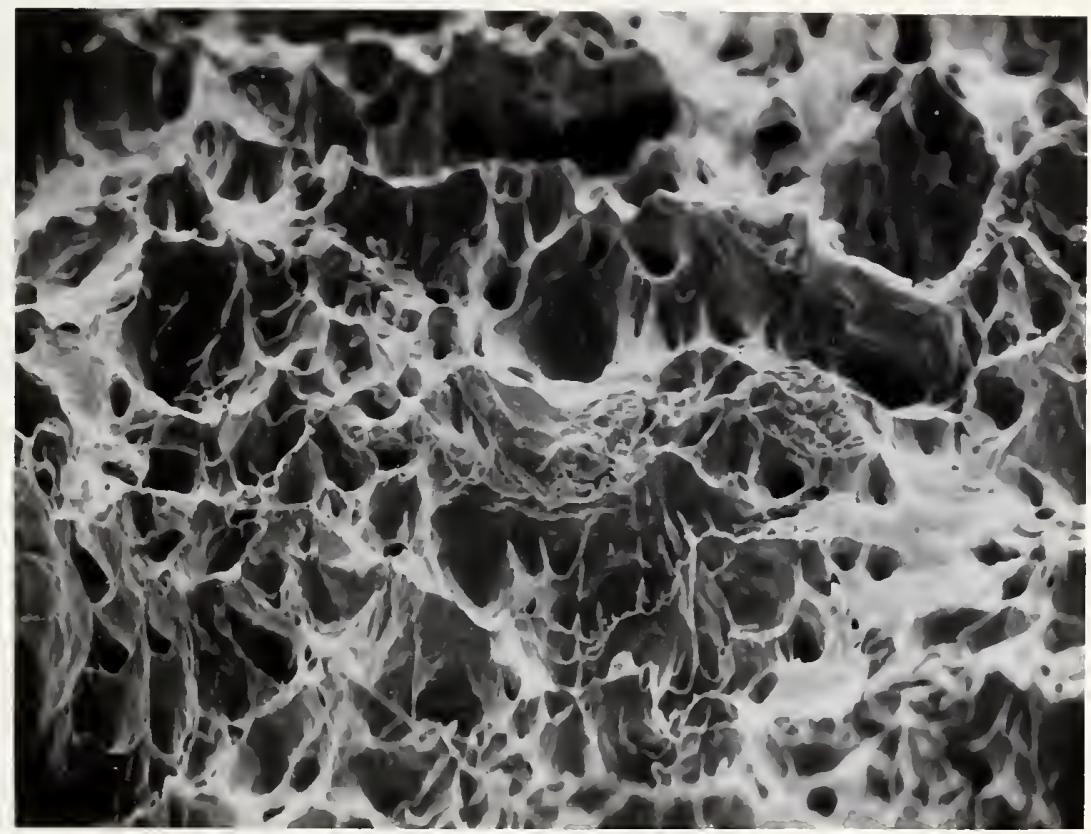

Figure 11. SEM of the fracture surface of the NBS produced uniaxial tensile test of material from the submitted failure (test D) showing dimpled rupture. X 750

Figure 12. Unetched longitudinal cross section through the submitted failed pipe showing the representative inclusion content. X 100 


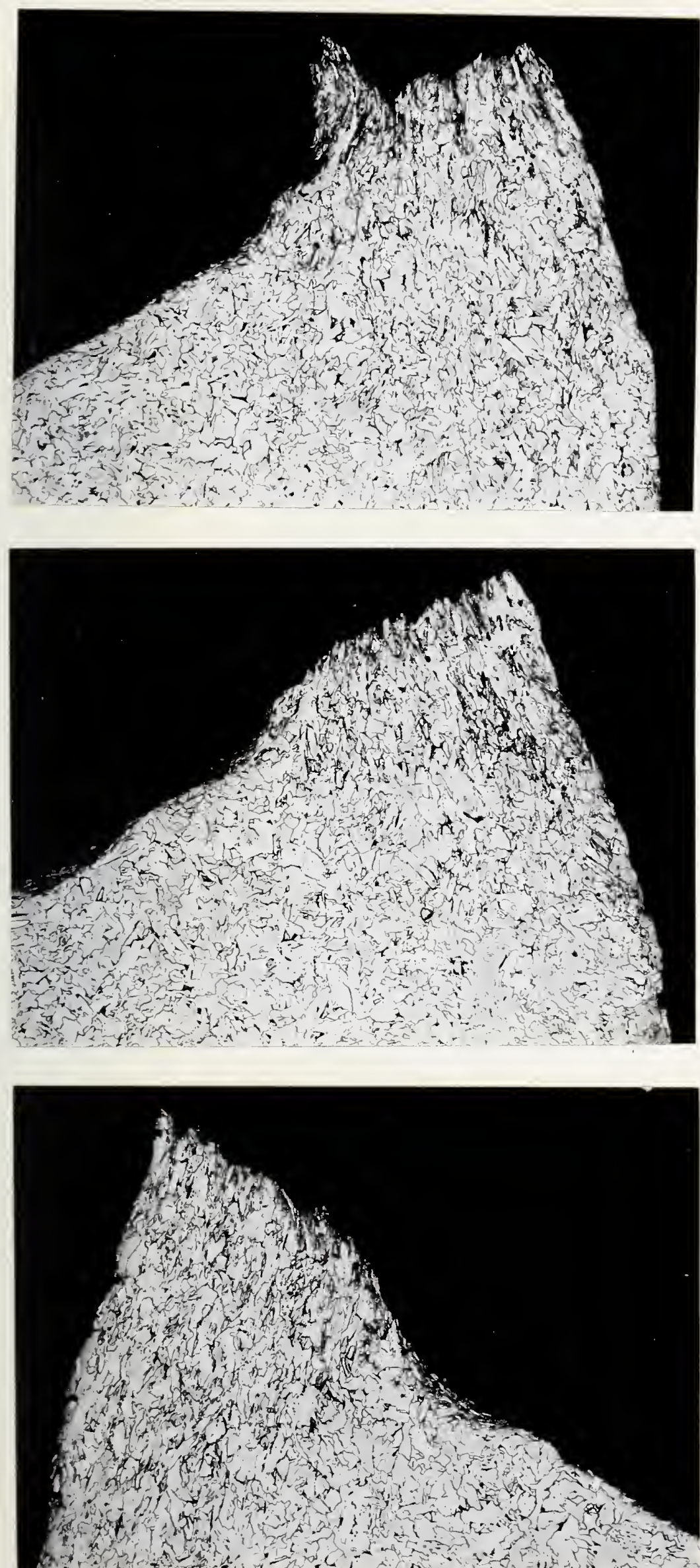

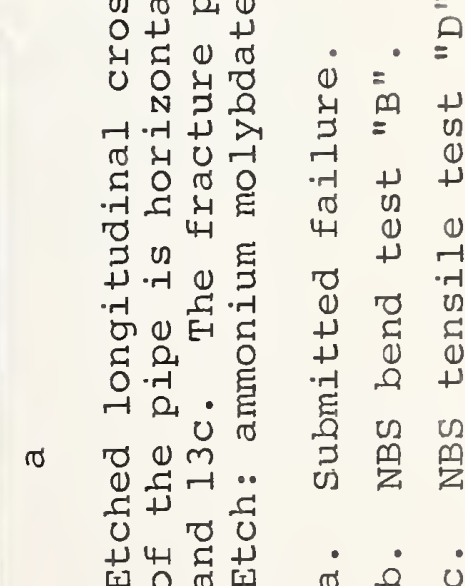





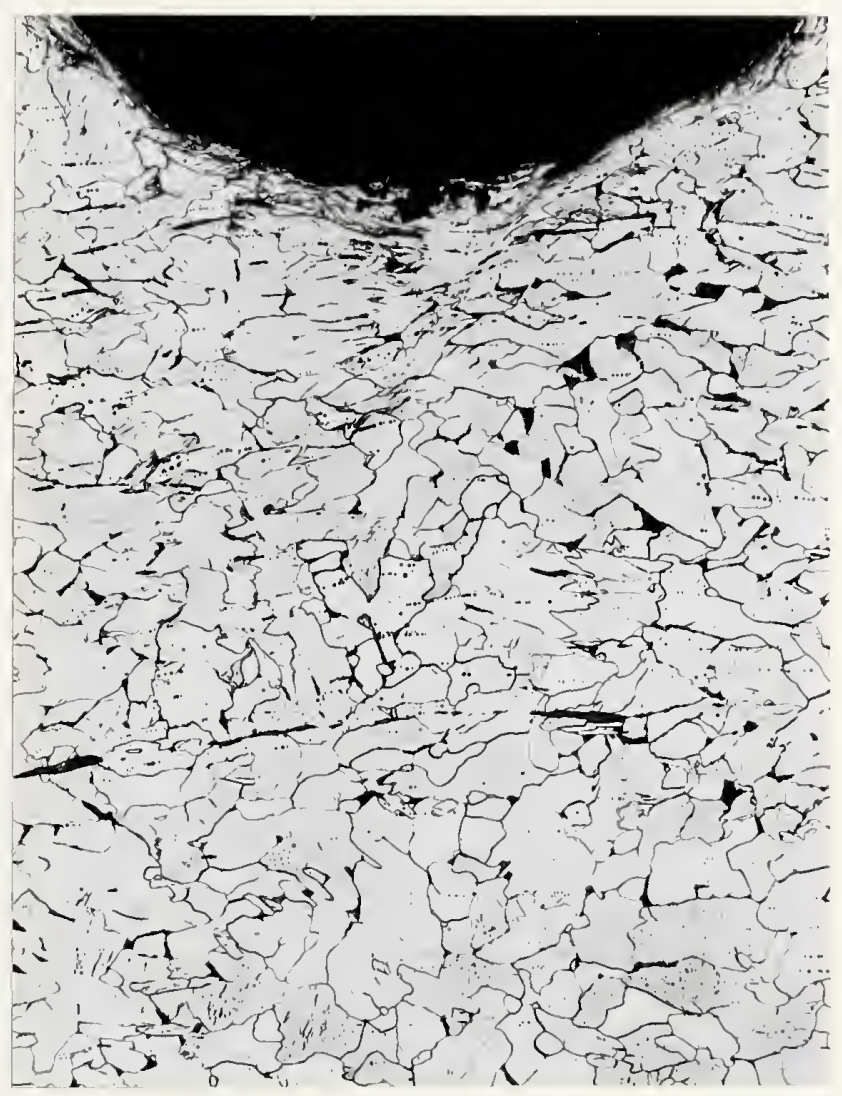

Figure 14. Etched longitudinal cross section through submitted fractured pipe showing deformation at and near the root of the thread one thread removed from the fracture. Etch: ammonium molybdate. X 100 



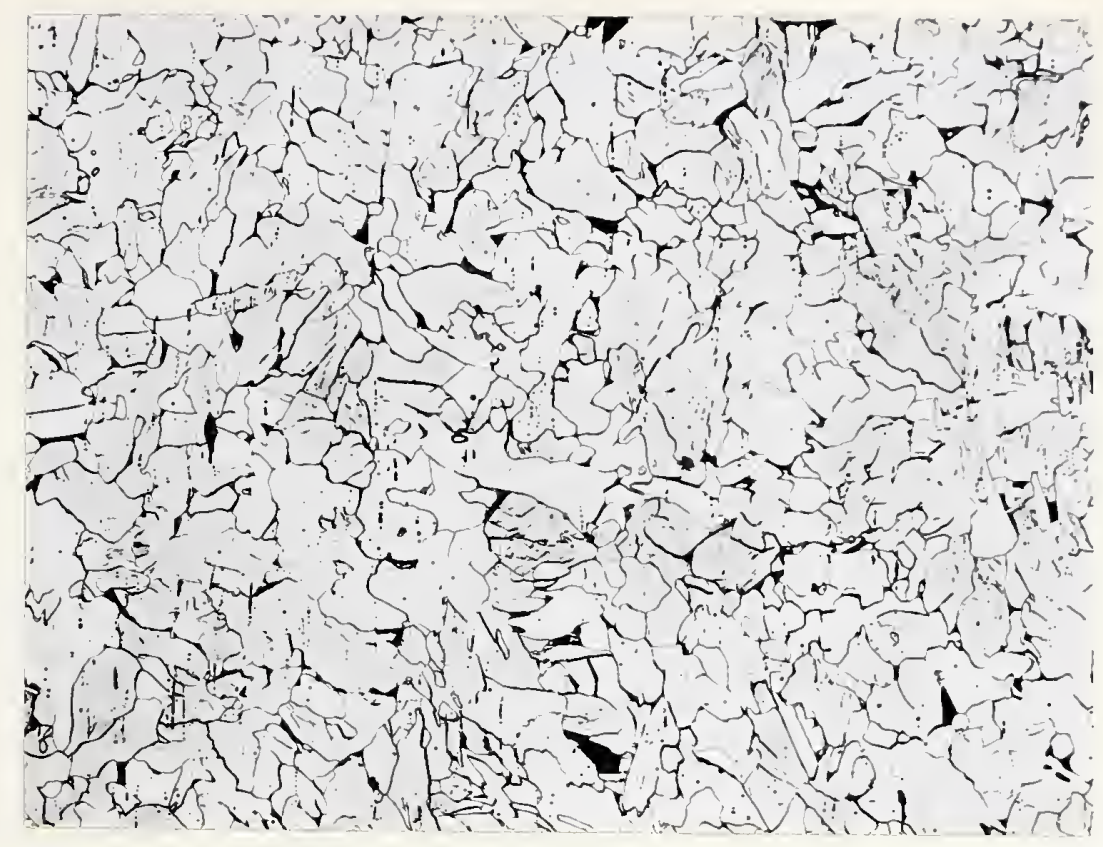

Figure 15. Etched longitudinal cross section through submitted failed pipe showing representative microstructure which consists primarily of ferrite (white) and a small amount of pearlite (dark patches).

Etch: ammonium molybdate. X 100

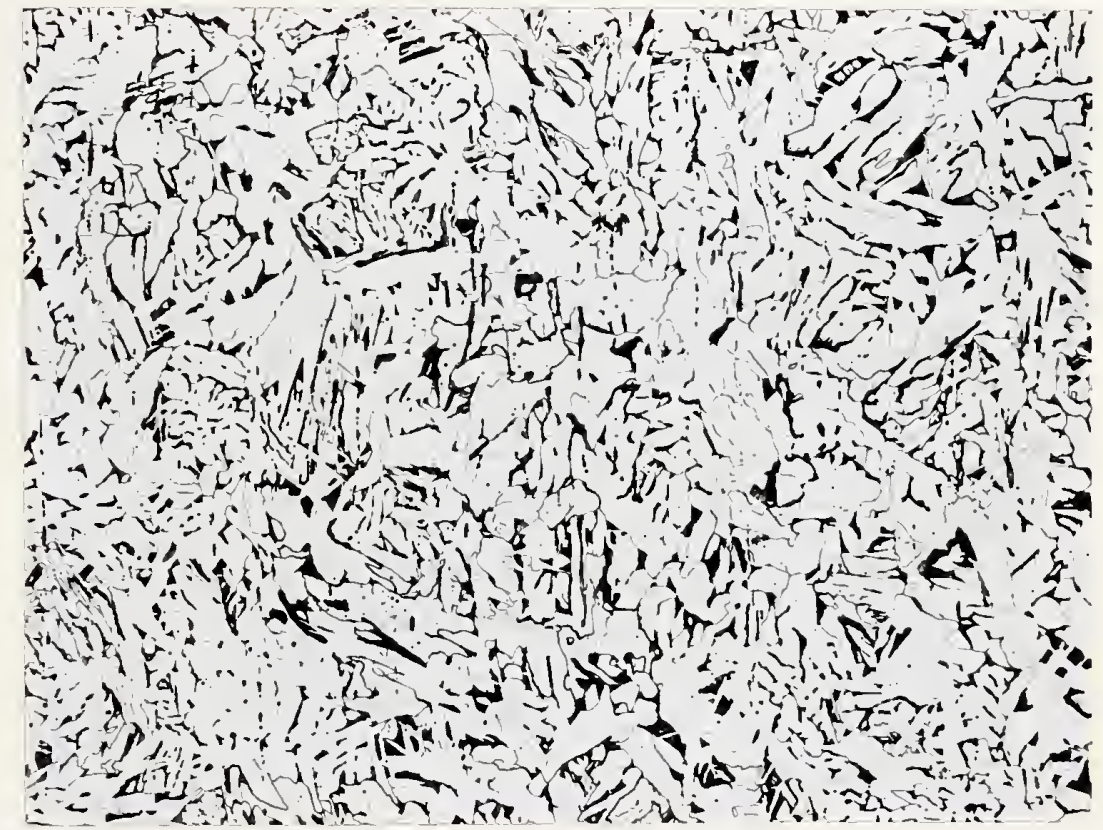

Figure 16. Etched representative longitudinal cross section through stock standard weight black iron pipe used for tests $A$ and $C$. The microstructure consists of ferrite (white) and pearlite (dark patches). There is some evidence of a Widmanstätten structure.

Etch: 3용 Nital. X 100 



\begin{tabular}{|c|c|c|}
\hline $\begin{array}{l}\text { U.S. DEPT. OF COMM. } \\
\text { B!BLIOGRAPHIC DATA } \\
\text { SHEET }\end{array}$ & $\begin{array}{l}\text { 1. PURLICATION OK RESPORT NO. } \\
\text { NBSIR } 73-264\end{array}$ & 3. Recipient's Accession No. \\
\hline \multicolumn{2}{|l|}{ 4. TITLEE A.VD SULTITI.F } & 5. Publication Date \\
\hline \multirow{2}{*}{\multicolumn{2}{|c|}{$\begin{array}{l}\text { EXAMINATION OE FAIJED ONE INCH BLACK IRON PIPE } \\
\text { NATURAL GAS SERVICE LINE, IOWA PUBLIC SERVICE } \\
\text { COMPANY, EAGLE GROVE, IOWA. }\end{array}$}} & August 30,1973 \\
\hline & & 6. Performing Organization Codc \\
\hline \multicolumn{2}{|l|}{$\begin{array}{l}\text { 7. AUTHOR(S) } \\
\text { T. Robert Shives }\end{array}$} & $\begin{array}{l}\text { 8. Performing () ganizatun } \\
\text { NBSIR 73-264 }\end{array}$ \\
\hline \multicolumn{2}{|c|}{ 9. PERF ORMING ORGANIZATION NAME AND ADDRESS } & $\begin{array}{l}\text { 10. Project/Task/ hiork Unit No. } \\
3120418\end{array}$ \\
\hline \multicolumn{2}{|c|}{$\begin{array}{l}\text { NATIONAL BUREAU OF STANDARDS } \\
\text { DEPARTMENT OF COMMERCE } \\
\text { WASIIINGTON, D.C. } 20234\end{array}$} & 11. Contract/Grant Wo. \\
\hline \multirow{2}{*}{\multicolumn{2}{|c|}{$\begin{array}{l}\text { 12. Sponsoring O-ganization Name and Address } \\
\text { Office of Pipeline Safety' } \\
\text { Department of Transportation } \\
\text { Washington, D. C. } 20590\end{array}$}} & $\begin{array}{l}\text { 13. Type of Report \& Period } \\
\text { Covered Failure } \\
\text { Analysis Report }\end{array}$ \\
\hline & & 14. Sponsoring A gency Code \\
\hline
\end{tabular}

15. SUPPLE.MENTARY NOTES

16. ABSTRACT (A 200-word or less factual summary of most significant information. If document includes a significant bibliography or literature survey, mention it here.)

A fractured one inch black iron pipe natural gas service line which connected to a building involved in an explosion and fire in

Eagle Grove, Iowa, on February 2, 1973, was examined by the NBS

Mechanical Properties Section. The fracture was ductile in nature.

There was no evidence found to indicate the presence of a preexisting crack. The fracture appeared to have been due to bending stresses caused by loading from an external source.

17. KEY WORDS (Alphatetical order, separated by scmicolons)

Black iron pipe; dimpled rupture; ductile fracture; gas pipe.

18. AVAILABILITY STATEMENT

$\square$ UNLIMITED.

X FOR OFFICIAL DISTRIBUTION. DO NOT RELEASE TO NTIS.

\begin{tabular}{|l|c|}
\hline $\begin{array}{l}\text { 19. SECURITY CLASS } \\
\text { (TIIS REPORT) }\end{array}$ & 23 \\
UNCL ASSIFIED & 23 OF PAGES \\
\hline $\begin{array}{l}\text { 20. SECURITY CLASS } \\
\text { (THIS PAGE) }\end{array}$ & 22. Price \\
UNCLASSIFIED & \\
\hline
\end{tabular}




